\title{
EXPULSION FROM THE SYNAGOGUE?
}

\author{
RETHINKING A JOHANNINE ANACHRONISM
}

Edward W. Klink III

\begin{abstract}
Summary
The 'expulsion from the synagogue' in John 9 has been dominated for nearly four decades by reconstructed 'glimpses' popularized in the two-level reading of the Fourth Gospel by J. Louis Martyn. The key insight Martyn provided the last generation of students of John is the anachronism in 9:22, an insight that although it has been criticized at the level of historical reconstruction (the official edict of the Jamnia Academy and the Birkat-ha-Minim), has dominated nearly every reading of the gospel. But Martyn has guided us to an exaggerated reading of the 'expulsion from the synagogue' passages, and his focus on the situation behind John has minimized the Gospel's explicit

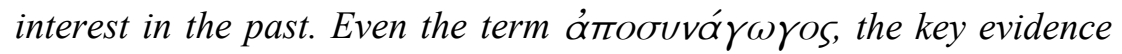
for Martyn, reflects a historicity that has been too easily suppressed. This paper will argue that a fresh examination of the historical reflections in the 'expulsion of the synagogue' passage in John 9 reveals not only John's theological interest in the past, but also some potential 'glimpses' on the life and ministry of the historical Jesus.
\end{abstract}

\section{J. L. Martyn and the 'Expulsion from the Synagogue'}

Every student of the Gospel of John since the late 1960's has been greatly advantaged in their reading of the gospel by the reading strategy of J. Louis Martyn. It was the seminal work by Martyn ${ }^{1}$ that

1 Martyn, History and Theology in the Fourth Gospel, 3d, ed., NTL (Louisville: Westminster John Knox, 2003). The second revised and enlarged edition was published in 1979. A third edition, unchanged from the second, was recently published in 2003; this third edition is the text from which all subsequent discussion will take 
popularized the two-level reading of the Fourth Gospel. Martyn did not create the two-level reading of the FG without warrant. The clues he has found in the healing of the blind man in John $9^{2}$ have made the pericope famous, for it is the entry point from which Martyn sees the two-level drama. When reading John 9 Martyn finds as blatantly

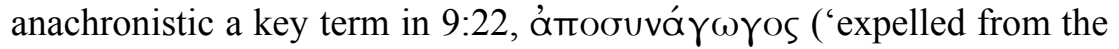
synagogue'). Although in the narrative this term describes an event during Jesus' earthly ministry, for Martyn it is most certainly dealing with an event that could not have occurred until decades after Jesus' life. Even more, rather than just a vague reference to something during the time of the evangelist, Martyn is convinced that the 'expulsion' term 'refers to the action taken under Gamaliel II to reword the Birkat ha-Minim so as to make it an effective means for detecting Christian heresy. ${ }^{3}$ In this way, the 'Jews' in 9:22 is the evangelist's way of referring to the Jamnia Academy. Thus, Martyn is convinced that the first-century readers of the gospel would have seen each of the primary characters in the narrative as referring to persons in their present setting, based upon the anachronistic insertion of the 'expulsion from the synagogue' statement. In many ways, the 'expulsion from the synagogue' term in 9:22 is the key to his reading of the Fourth Gospel.

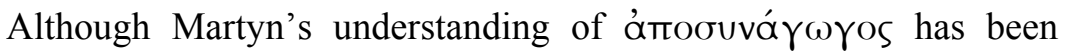
heavily criticized by historians of first-century Judaism and early Christianity, his reading is still the dominant reading of the gospel. It was Gail O'Day who recently pointed out that one of the dangers with Martyn's reconstruction of the Gospel was that his reading strategy

...blocked out for a while all other ways both of reading the Gospel and of reading the historical data. Martyn's reading became totalizing, not because his claims or even his intentions and methods were totalizing, but because he read so well and so easily that we forgot it was a

place from. John Ashton, Understanding the Fourth Gospel (Oxford: Clarendon, 1991), claims that it 'is probably the most important single work on the gospel since Bultmann's commentary' (107). Something similar is stated by D. Moody Smith, 'The Contribution of J. Louis Martyn to the Understanding of the Gospel of John,' in R. T. Fortna and B. R. Gaventa (eds.), The Conversation Continues: Studies in Paul and John, J. L. Martyn Festschrift (Nashville: Abingdon, 1990): 'Martyn's thesis has become a paradigm, to borrow from Thomas Kuhn. It is a part of what students imbibe from standard works, such as commentaries and textbooks, as knowledge generally received and held to be valid' (293, n.30).

2 Although the 'expelled from the synagogue' term also appears in 12:42 and 16:2, we will focus on 9:22 where Martyn spends the majority of his time.

3 Martyn, History and Theology in the Fourth Gospel: 65. 
construction of the data. We ... read Martyn instead of rereading the data.... 4

Such a warning provides warrant for a fresh appraisal of the historical 'glimpses' in the gospel narrative. Therefore, with a sense of fear before such a dominant paradigm, this article will argue that Martyn has guided us to an exaggerated reading of the 'expulsion from the synagogue' passages, especially in chapter 9. After providing a fresh examination of the historical reflections in the 'expulsion of the synagogue' passage in John 9, this paper will argue that John 9 reveals not only John's theological interest in the past, but also some potential 'glimpses' of the importance of the Johannine Jesus for the readers of John.

\section{Consensual Criticism of a Consensus}

Martyn argued that what we needed was to 'sharpen our senses ... to perceive elements in the Gospel which are clues to the circumstances in which it was written.' 5 The clue, for Martyn, is located primarily in one word in chapter 9. After examining the three texts that use the term ámoouvó $\gamma \omega \gamma$ ○s, Martyn attempts to fill out the picture concerning the use of this word for John: 'At some point prior to John's writing, an authoritative body within Judaism reached a formal decision regarding messianic faith in Jesus. Henceforth, whoever confesses such faith is to be separated from the synagogue.' 6 Martyn squeezes as much information out of the term as possible, but is forced to admit with those who have gone before him that 'Beyond this minimal definition one is clearly involved in interpretation.' ${ }^{7}$

There has been almost unanimous agreement that Martyn's referent of the Birkat ha-Minim in John 9 is historically inaccurate. ${ }^{8}$ Since the

4 Gail R. O'Day, 'Response: “The Expulsion from the Synagogue: A Tale of a Theory"' (unpublished paper, annual meeting of the SBL, Toronto, Canada, November 25, 2002): 5 .

5 Martyn, History and Theology in the Fourth Gospel: 30.

6 Martyn, History and Theology in the Fourth Gospel: 49

7 Martyn, History and Theology in the Fourth Gospel: 50.

8 Martyn was not the first to place these 'expulsion' passages in the context of Jewish-Christian dialogue involving the Fourth Gospel. The earliest example can be found in William Wrede, Charakter und Tendenz des Johannes-evangeliums, SVSGTR 37 (Tübingen: Mohr, 1933), who argued that the Jews in John reflected a Johannine conflict with contemporary Judaism. But it was Kenneth L. Carroll, 'The Fourth 
late 1970's and early 1980's, after the second edition of History and Theology in the Fourth Gospel was published, there have been several major critiques of Martyn's use of the Birkat ha-Minim, ${ }^{9}$ as well as several studies of its effects in early Jewish-Christian relations. ${ }^{10}$ Although Johannine scholars were enthusiastic for a proposal that seemed to work, rabbinic experts and other historians could not be persuaded. ${ }^{11}$ Several irresolvable problems were noted concerning Martyn's thesis: doubt concerning the kind of general authority to be given to the Jamnian Academy within the first century; ${ }^{12}$ the date of the Twelfth Benediction and the improbability of it being composed as

Gospel and the Exclusion of Christians from the Synagogues,' BJRL 40 (1957): 19-32, who aligned the 'expulsion' passages with the Birkat ha-Minim. At nearly the same time, T. C. Smith, Jesus in the Gospel of John (Nashville: Broadman, 1959), made a similar connection.

9 For the critiques of Martyn's use of the Birkat ha-Minim and its general use in the first-century see Günter Stemberger, 'Die sogenannte "Synode von Jabne" und das frühe Christentum,' Kairos 19 (1977): 14-21; Peter Schäfer, 'Die sogannante Synode von Jabne: Zur Trennung von Juden und Christen im ersten/zweiten Jh. n. Chr,' in Studien zur Geschichte und Theologie des Rabbinischen Judentums, AGAJU 15 (Leiden: Brill, 1978): 45-64; Reuven Kimelman, 'Birkat ha-Minim and the Lack of Evidence for an Anti-Christian Jewish Prayer in Late Antiquity,' in E. P. Sanders et al. (eds.), Jewish and Christian Self-Definition, 3 vols. (London; SCM Press, 1981): vol. II: 226-44; William Horbury, 'The Benediction of the Minim and Early JewishChristian Controversy,' JTS 33 (1982): 19-61; and Steven T. Katz, 'Issues in the Separation of Judaism and Christianity After 70 C. E.: A Reconsideration,' JBL 103 (1984): 43-76; Stephen G. Wilson, Related Strangers: Jews and Christians 70-170 C.E. (Minneapolis: Fortress, 1995): 169-94; Stephen Motyer, Your Father the Devil? A New Approach to John and 'the Jews, ' PBTS (Carlisle: Paternoster, 1997): 92-94; and Daniel Boyarin. 'Justin Martyr Invents Judaism,' CH 70 (2001): 427-61. Yet, even amidst all these reservations, Martyn, History and Theology in the Fourth Gospel: 60, n.69; 61-62, n.75, only speaks with caution; and Wayne Meeks, 'Breaking Away: Three New Testament Pictures of Christianity's Separation from the Jewish Communities,' in Jacob Neusner and Ernest S. Frerichs (eds.), 'To See Ourselves as Others See Us:' Christians, Jews, and 'Others' in Late Antiquity (Chico, Calif.: Scholars Press, 1985): 93-115, merely prefers to think of a linear development in which the promulgation of the Birkat ha-Minim was a culmination rather than the beginning of a development.

10 Philip L. Mayo, 'The Role of the Birkath Haminim in Early Jewish-Christian Relations: A Reexamination of the Evidence,' IBR 16.2 (2006): 325-44. Cf. David Aune, 'On the Origins of the "Council of Javneh" Myth,' JBL 110 (1991): 49-193; and Peter W. van der Horst, 'The Birkat ha-minim in Recent Research,' in Hellenism Judaism - Christianity: Essays on Their Interaction, Pieter W. van der Horst, 2d ed. (Leuven: Peeters Press, 1998): 113-24.

11 Similarly stated by D. Moody Smith, 'Postscript for Third Edition of Martyn, History and Theology in the Fourth Gospel,' 19.

12 The first three problems are from D. Moody Smith, 'The Contribution of J. Louis Martyn to the Understanding of the Gospel of John,' History and Theology in the Fourth Gospel: 7. 
early as the 80's of the first century; the lack of direct evidence that the Benediction was formulated for the purpose of removing Christians from the synagogue, or that it was ever even used that way; the inability to limit the meaning of Minim to anything less than 'heretic';13 and the late date of the pertinent sources.

The developing response over the last few decades to Martyn's thesis and the Johannine link to the Jewish-Christian split can now be stated in two related points. ${ }^{14}$ First, interpreters have consistently credited Christianity, their primary interest, with too great a role in Jewish developments after AD 70. As Stephen Wilson argues, the Jamnia sages 'were not obsessed with Christians and certainly not with them alone. Apart from promoting a number of complex and necessary adjustments to postwar conditions, they also had to deal with Gnostics, apocalypticists, hellenizers, and various other "nonrabbinic", but thoroughly Jewish, groups. ${ }^{\prime 5}$ A statement by Kimelman is more to the point:

One of the results of ... this volume was a highlighting of the lack of evidence for any formative impact of Christianity on any major element of tannaitic Judaism, including the development of rabbinic law, the formation of the Mishnah, the structuring of the liturgy, the closing of the canon, and the major propositions of rabbinic theology. This itself is sufficient to question the thesis that birkat ha-minim was primarily directed against Christianity. We must be careful of anachronistically overestimating the impact of Christianity on Judaism in the first two centuries. ${ }^{16}$

Second, the influence of the Jamnia sages between AD 70 and 135 and beyond should not be overestimated. Again, according to Wilson, 'The rabbinic account of the Birkat ha-minim is ... a retrospective, punctiliar summary of what was in reality a lengthy process. The spread of their

13 Once Minim loses any specific denotation, the Benediction loses its force in the Johannine narrative. Kimelman, 'Birkat ha-Minim and the Lack of Evidence,' rightly shows that there is unambiguous evidence that the term Min can denote a deviant Jew (228). As Kimelman explains, 'Thus, in Palestinian literature, be it tannaitic or amoraic, it is reasonable to conclude that minim had a Jewish sectarian denotation and was not used to refer to Gentiles' (230). This does not deny the developing use of the term, but it does require more contextual complexity by any argument making use of the term (231). The same goes for the term nosrim, which cannot have been in the earliest form of the Benedictions. Cf. Schäfer, 'Die sogannante Synode von Jabne.'

14 This is adapted from Wilson, Related Strangers: 180-81, and is seconded by Boyarin, 'Justin Martyr Invents Judaism,' 428-29.

15 Wilson, Related Strangers: 180-81.

16 Kimelman, 'Birkat ha-Minim and the Lack of Evidence,' 233 (emphasis added). 
influence was gradual and almost certainly did not encompass all Jewish communities until well beyond the second century.' ${ }^{17}$ Daniel Boyarin wants to make Wilson's conclusion even more explicit, claiming that the process was lengthy and the earliest evidence is from the mid-third century and not before. Although William Horbury tried over 20 years ago to readmit Justin's reference to a Jewish awareness of Christians as worthy evidence, his inclusion of Justin is still unable to explain the formal, liturgical curse in the Benedictions, which includes the Birkat ha-Minim. ${ }^{18}$ Even more, Horbury admits that Justin's evidence originates from the middle to late 150's, which he admits can only prove that such activity occurred from the second century onwards. ${ }^{19}$ Such an admission, claims Boyarin, already would discredit any attempt to use it as a pendant for the alleged Yavnean institution for the 'gap between [AD] 90 and 150 is huge....' 20

The above discussion of problems might be described as a rethinking of how Judaism worked toward self-definition. The exaggerated role of the Birkat ha-Minim in Martyn's argument is unable to accurately depict this Jewish-Christian controversy of identity - an issue to which we shall return shortly. But problems with Martyn's reading of John do not stop at the historical reconstruction located behind the text, but are also reflected in the narrative itself.

\section{3. 'Expulsion' in the Johannine Narrative}

Although the historical evidence for Jewish-Christian relations is intriguing, it alone is not the focus of this paper. A further chink in the armour of Martyn's thesis is the almost complete narrative impotence of the 'expulsion' motif in the rest of the Fourth Gospel. ${ }^{21}$ If the 'expulsion from the synagogue' is a hermeneutical key to the Gospel, as argued by Martyn and assumed thereafter, then it should be evident

17 Wilson, Related Strangers: 181.

18 William Horbury, 'The Benedictions of the Minim and Early Jewish-Christian Controversy,' JTS 33 (1982): 19-61.

19 Horbury, 'The Benedictions of the Minim and Early Jewish-Christian Controversy,' 24. As Horbury explains, 'They may be taken to indicate that, from the second century onwards, an imprecation on Christians was pronounced in synagogue' (27).

20 Boyarin, 'Justin Martyr Invents Judaism,' 435.

21 See Edward W. Klink III, The Sheep of the Fold: The Audience and Origin of the Gospel of John (SNTSMS 141; Cambridge: Cambridge University, 2007), for a moredetailed analysis of the key texts that Martyn uses to establish the community's plot. 
in the whole narrative of John, not just that one pericope. Even more, the 'expulsion' motif should be a controlling force over the rest of the narrative; other passages should, by necessity, function in light of the reality posited behind John 9 .

One of the only treatments of the disjunction between the reading by Martyn and the rest of the Johannine narrative has been done by Adele Reinhartz. ${ }^{22}$ Reinhartz attempted to apply Martyn's two-level reading strategy to the whole of the Gospel of John. Reinhartz examines two passages and applies to them the two-level reading strategy proposed by Martyn. The first passage Reinhartz examines is John 11:1-44, the story of the raising of Lazarus. This passage tells of the sisters, Mary and Martha, who are in mourning for their recently-deceased brother Lazarus. Though apparently known to be related to Jesus, even called his beloved, these women have clearly not been excluded from the Jewish community, as evidenced by the fact that they are comforted in their grief by 'many of the Jews' (11:19). As Reinhartz explains,

If we apply the two-level reading method to this passage, we arrive at a scenario whereby the sisters represent the Johannine believers, of the Johannine community towards the end of the first century, and the Jews who comfort them represent the majority of the Jewish community that does not believe Jesus to be the messiah. If, as the consensus view asserts, Christ-confessors had already been excluded from the synagogue and hence from the Jewish community as a whole, how is it that these two women are surrounded by Jewish mourners? ${ }^{23}$

The second passage Reinhartz examines is John 12:11, where it states that on account of Jesus 'many of the Jews were going over to Jesus and putting their faith in him.' They were believing in Jesus because they witnessed Jesus raise Lazarus from the dead. As Reinhartz explains,

In this case, the narrator, perhaps representing the views of the evangelist and/or the Johannine community, views belief in Jesus as the Christ as incompatible with membership in the Jewish community, yet it does not refer in any way to an official Jewish policy of expulsion. On

22 Adele Reinhartz, 'The Johannine Community and its Jewish Neighbors: A Reappraisal,' in What is John? Vol. II Literary and Social Readings of the Fourth Gospel, ed. Fernando F. Segovia (SBLSS 7; Atlanta: Scholars Press, 1998): 111-38; and 'Exclusion, Expulsion, Desertion: The Rhetoric of Separation in the Gospel of John,' (unpublished paper, John, Jesus, and History Group at the Annual Meeting of the SBL, San Antonio, TX, November 21, 2004). Although the two works have much overlap, the following quotations come from the more recent paper.

23 Reinhartz, 'Exclusion, Expulsion, Desertion,' 9-10. 
the contrary, it refers to Christ-confessing Jews as deserterspresumably from the Jewish community. ${ }^{24}$

Neither of these two passages is able to function with Martyn's twolevel reading. In fact, if we are consistent with Martyn's reading strategy, we get two different 'glimpses' of the Johannine situation, a third if we include Martyn's own examination of the specific expulsion from the synagogue passages. Thus, it appears that we have either a very complex set of relationships between the Jews and Johannine Christians portrayed in the Johannine narrative, or the historical reconstruction proposed by Martyn is impossible to harmonize with the narrative as a whole.

But even more might be deduced by examining the narrative progression in John. Martyn's analysis of the narrative parts creates a completely different narrative whole. It is interesting that several times Martyn has to claim that he is not doing decoding work. ${ }^{25}$ Martyn's reconstruction would construct the narratives in the following chapter order: $9,12,16,5$, and 7 . Though first in narrative order, chapters 5 and 7 are actually later stages in the Johannine community's experience. It is $16: 2 \mathrm{~b}$ that links the three 'expulsion' passages $(9: 22$; $12: 42 ; 16: 2 a)$ with chapters 5 and 7 . Thus, the progression necessarily moves against the flow of the first level of the narrative. But when the narrative shows a necessary progression in its development, Martyn's narrative 're-ordering' becomes problematic. For example, an examination of the character of Nicodemus reveals that it is developed as the narrative progresses. John 3 is the initial and most detailed Nicodemus pericope, but Nicodemus is also discussed in a progressive manner in chapters 7 and 19. In 7:50 the narrative refers back to chapter 3 at the first mention of Nicodemus: 'who had gone to Jesus before.' The narrative assumes that the reader has already read chapter 3 before coming to chapter 7. Chapter 19 is no different. At the first mention of Nicodemus the narrative reminds the reader that he is the

24 Reinhartz, 'Exclusion, Expulsion, Desertion,' 10.

25 Martyn, History and Theology: 85, admits concerning his own reading of the narrative: 'At this point caution is necessary. Have we not overstepped the bounds of probability? The drama may indeed reflect two levels in general. But do we not press the case too far if we take these developments as reflections of actual events in John's milieu?' Later Martyn admits, 'I do not suggest that the dramatis personae can be explained in no other way. ... John was neither playing a kind of code-game, nor trying to instruct members of his church about points of correspondence between the Jewish hierarchy of Jesus' day and that of their own' (89). 
one 'who had at first come to Jesus by night.' Again, the narrative assumes that the reader has followed its own progression. Helpful here is the discussion of the narrative's progression or plot development by Alan Culpepper. ${ }^{26}$ Culpepper argues that John has a narrative development that is vital to its individual parts. Martyn disrupts the narrative's plot development for his own plot - a plot not found in the narrative of the Fourth Gospel. The realization that the Martyn 'expulsion' thesis has been so successfully criticized at the level of both history and narrative, forces us to examine further the exact nature of this 'expulsion from the synagogue'.

\section{4. 'Expulsion' in Judaism and Earliest Christianity}

What the consensual criticism and narrative analysis has demonstrated is that Martyn has been anachronistic in positing a broad JewishChristian conflict from as late as the fourth century onto a late first century Johannine text. This is no small miscalculation that merely requires an adjustment on the same line of a linear development, as Lindars or especially Meeks has argued, ${ }^{27}$ but reflects a distortion of the type of Jewish-Christian tension reflected in the Gospel. We hardly need Martyn's thesis to tell us that the Fourth Gospel reflects tensions between Jews and the Christians. Similar to O'Day's warning about reading Martyn because he read so well, Martyn's thesis distracts the modern reader of John from gauging the actual form and type of tension expressed by the gospel narrative. What is needed is a fresh examination of the possible concepts of 'expulsion' in the first century and a reflection on the nature of a heretic or Min.

26 Culpepper, Anatomy of the Fourth Gospel: A Study in Literary Design (Philadelphia: Fortress, 1983): 89-97. Although the Gospel has a wide variety of pericopae that each have an individual function, 'John allows each episode to have a meaningful place in the story' as a whole (97).

27 Wayne Meeks, 'Breaking Away,' 102. A similar idea is stated earlier by Barnabas Lindars, 'The Persecutions of Christians in John 15:18-16:4a,' in Suffering and Martyrdom in the New Testament, ed. William Horbury and Brian McNeil (Cambridge: Cambridge University Press, 1981): 48-69, esp. 50-51. Cf. John Ashton, Understanding the Fourth Gospel: 109, n. 102. Interestingly, Smith, 'The Contribution of J. Louis Martyn to the Understanding of the Gospel of John,' seems to assume that Martyn would have also seen the 'expulsion' as 'the culmination of a long struggle, first within the synagogue and then between synagogue and church, developing over many years' (18). 
The Concept of Expulsion. The problem with the term ámoouvá $\gamma \omega \gamma$ ○os is that we have no literary evidence for its potential sense. ${ }^{28}$ Recent study has furthered our understanding of Jewish conflicts, even conflict between differing Jewish groups. The historical criticisms mentioned above tend to emphasize one important point: The Jewish-Christian conflicts in the first century reveal complex tensions that appear to have been intra-Jewish in nature. It was a familial conflict. As Kimelman explains, 'there is abundant evidence from patristic sources that Christians were frequenting the synagogues quite often. Indeed, there is far-flung evidence that it was the church leadership that strove to keep Christians away from the synagogue and not Jews who were excluding them.' ${ }^{29}$ Although this evidence is after the first century, it may show a more accurate linear progression-one of continuing conflict through interrelation and dialogue. Although a shift eventually occurred, it was not until long after the first century. In fact, Daniel Boyarin argues convincingly that the evidence from Justin Martyr and other sources reflect not a Jamnia-type break between Jews and Christians, but a gradual development of the idea of a 'heretic.' 30 According to Boyarin, it was not until the third or fourth century that 'heretic' meant anything different from 'a party or sect marked by common ideas and aims.' 31 Thus, as Boyarin explains, 'It follows that in the later part of the first century the notion of heresy had not yet entered (pre)-rabbinic Judaism, and that the term min — only attested ... in the late second-century sources - is in fact a later development in Jewish religious discourses. ${ }^{32}$

Evidence for this intra-Jewish conflict between Jews and Christians is hardly lacking. Although the evidence is after the first century, it surely reflects an important glimpse into the developing understanding of heresy, leading to two distinct 'groups'. A few examples are in

\footnotetext{
28 Let alone a referent, which is where most commentators spend their time.

29 Kimelman, 'Birkat ha-Minim and the Lack of Evidence,' 239.

30 Boyarin, 'Justin Martyr Invents Judaism,' 438-39.

31 Boyarin relies heavily on the research of Alain Le Boulluec, La notion d'hérésie dans la literature grecque II ${ }^{e}-I I I^{e}$ siècles (Paris: Études Augustiniennes, 1985).

32 Boyarin, 'Justin Martyr Invents Judaism,' 439-40. D. Moody Smith's response to Boyarin in the 'Postscript for the Third Edition of Martyn' (20) is telling, for he merely throws the comment by Ashton back at him: 'But the plausibility of the hypothesis depends on the light it sheds on the Gospel...' (Ashton, Understanding the Fourth Gospel: 109, n. 102). But this still confuses the concept of expulsion in the manner of Meeks.
} 
order. ${ }^{33}$ The Council of Elvira in AD 306 leaves the impression that Jews and Christians must have had intimate social relations. ${ }^{34}$ Canon 16, for example, prohibits marriage between a Jew and a Christian unless the Jew is willing to be converted to Christianity. Neither laity nor clergy were allowed to accept any hospitality from Jews. The council had prohibition against adultery between Christians, but added a further law which expressly prohibited adultery between Jews and Christians. In the Canons of Laodicea, ${ }^{35}$ a fourth-century collection of church regulations, similar prohibitions are found. In Canon 29 it states the following: 'Christians shall not Judaize and be idle on Saturday, but shall work on that day; but the Lord's Day they shall especially honor, and, as being Christian, shall if possible, do no work on that day. If, however, they are found to be Judaizing, they shall be shut out from Christ.' There are also instructions to make sure to read the Gospels on Saturday as well as Sunday. Although this may imply that services were held on both days, it may also reflect a warning to Christians who only read the Jewish Bible on Saturday, saving the Gospels for Sunday. There were also extensive debates between Jews and Christians. In Contra Celsum, for example, Origen seems to show an awareness of what Jews were really like, and even mentions debates with Jews. ${ }^{36}$ Liturgical materials (prayers and hymns, the ordering of the calendar, the celebration of festivals) contain a wealth of material pointing to continued contact between Jews and Christians, even into the later patristic period. ${ }^{37}$ The evidence from rabbinic materials is more veiled and obscure than most Christian material. An examination of Jewish sources places us squarely in the scholarly debate concerning the Minim, the topic of this article. With a broadening understanding of the Minim, or at least an understanding of its expanding function, our discussion above works well with the patristic sources.

The evidence from the second to fifth century, therefore, 'makes it apparent that Christians and Jews continued to have contact with each

33 The following is adapted from Robert L. Wilken, Judaism and the Early Christian Mind: A Study of Cyril of Alexandria's Exegesis and Theology (New Haven: Yale University Press, 1971): 25-38.

34 Friedrich Lauchert, ed., Die Kanones der wichtigsten altkirchlichen Concilien: Nebst den Apostolischen Kanones (Frankfurt am Main: Minerva, 1961).

35 Lauchert, Die Kanones.

36 Origen, Contra Celsum, trans. Henry Chadwick (Cambridge: Cambridge University, 1953): 1.45, 49, 55; 6.29 .

37 Wilken, Judaism and the Early Christian Mind: 30. 
other well into the fifth century,' 38 and that both Christians and Jews devoted a good part of their exegetical, theological, and 'ecclesial' endeavors to dealing with their continued shared existence. This is a difference in kind from Martyn's thesis which posits two distinct and unrelated entities in conflict during the first century, Judaism and Christianity. The linear progression modification of Meeks is only different in degree, for he too is forced to assume a fairly monolithic understanding of each group, just at a more localized level. But the evidence does not seem to reflect such a reality, at least not for a full century or more after John. Rather, the evidence from history reveals a familial conflict that took centuries to define. Before we turn to the definition assumed by John, it might be valuable to explore further the intra-Jewish concept of a 'heretic'.

'Heretic' as an Intra-Jewish Concept. It appears, then, that our examination of the Jewish-Christian conflict represented by John must take into account the intra-Jewish nature of such first century tensions. What has been at the centre of the discussion is the enigmatic term Minim. Thus far we have confirmed that the term can only anachronistically be limited to 'Christian' in the late first century. Rather, it seems to have been used with the more generic sense of 'heretic'. A recent article by David Instone-Brewer provides some helpful definition to the use of the term even before AD 70. ${ }^{39}$ InstoneBrewer examines the fragment of one version, which he calls Schechter's Geniza fragment, ${ }^{40}$ of the Eighteen Benedictions which appears to preserve wording which originates from the Second Temple period. When comparing the fragment with the earliest Babylonian version of the Benedictions, Instone-Brewer notes there is a change in language about the temple, specifically in benediction number 14, where the Geniza fragment assumes the Temple is still standing whereas the Babylonian version, with its phrase 'return in compassion

38 Wilken, Judaism and the Early Christian Mind: 36.

39 David Instone-Brewer, 'The Eighteen Benedictions and the Minim before 70 C.E.,' JTS 54 (2003): 25-44.

40 Instone-Brewer admits that 'The origins and original wording of the Eighteen are probably now impossible to reconstruct, though their form goes back before the first century, because very similar ideas and even wording are found in various ancient sources.... It is probable that there was no single version of this prayer in the early centuries because prayers were not fixed until at least the second century, and probably much later. However, it is also likely that the areas where variation was permitted were carefully limited, and local versions would become popular and semi-fixed' (26). 
and build her soon in our days,' assumes it is destroyed. ${ }^{41}$ This strongly suggests that the text of the Geniza fragment originated before AD 70. More important, and directly related to this paper, is what InstoneBrewer suggests concerning the use of the term Minim in benediction number 12: the term refers to the Sadducees when they had the high priesthood during the Second Temple period. Instone-Brewer admits that the term Minim was flexible, and 'In later rabbinic writings the ... term ... Minim continued to be used, either as a general reference to 'heretics', or as a reference to Christians,' ${ }^{42}$ but it shows at least two things. First, the term Minim performed an important function in the midst of intra-Jewish conflict between various 'groups', and was flexible to be used to refer to a diverse number of groups-Sadducees, Samaritans, and Christians all had the honour. ${ }^{43}$ Second, the term both originated and functioned before $\mathrm{AD} 70$, well before the time scholars assume the Gospel of John was written, in the early period of the Christian movement.

The above discussion has only confirmed that the Jewish-Christian conflict portrayed in the Gospel of John must reflect an intra-Jewish tension that was common in and around the time of the Gospel's origin. Not only does the historical evidence require the rejection of a singular expulsion verdict as argued by Martyn, but it also requires the rejection of the modified version proposed by Meeks and others, who see the verdict as a linear progression between two established groups. Rather, the Jewish-Christian tension in the first century was part of the larger intra-Jewish tension between related members of common familial roots. To describe the warring parties as unrelated groups is guilty of being anachronistic. We now turn our attention to the Johannine evidence.

\section{A Most Common Anachronism}

As we return to the enigmatic 'expulsion from the synagogue' passages in the Fourth Gospel, we approach them with a refreshed paradigm for understanding the Jewish-Christian conflict in the first century as an

41 Instone-Brewer, 'The Eighteen Benedictions and the Minim before 70 C.E.,' 34

42 Instone-Brewer, 'The Eighteen Benedictions and the Minim before 70 C.E.,' 42.

43 Instone-Brewer, 'The Eighteen Benedictions and the Minim before 70 C.E.,' 39. For similar evidence from the Mishnah see Boyarin, 'Justin Martyr Invents Judaism,' 440-46. 
intra-Jewish conflict in existence well before AD 70. An immediate

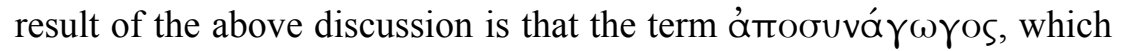
according to Martyn reflects a tension that could not have occurred before the late first century, can no longer qualify as an anachronism. ${ }^{44}$ On the contrary, the tension in and around 'the synagogue' was a most common event between Jewish groups, including first-century Christians, a group defining itself both within and beyond what we now call Judaism. This explains why the rest of the Johannine narrative not only is unaffected by what should have been the controlling influence of the 'expulsion' passages, but also is seen to conflict with the second-level drama assumed by Martyn.

So what kind of tension is John portraying? One of the key issues

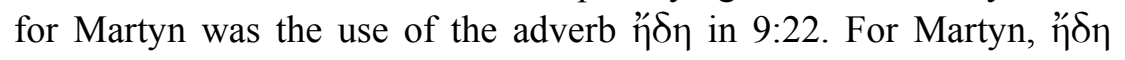
emphasizes that the 'agreement' or 'decision' made by the Jews had been reached some time prior to John's writing. And since this 'decision' was the Birkat ha-Minim, then such a suggestion is blatantly anachronistic. But if we cannot begin with the assumption that the 'agreement' is as formal as the Birkat ha-Minim then we are not able to read the expression as an anachronism. Martyn understands this agreement to be specifically for John and his readers. ${ }^{45}$ But our examination of expulsion and heresy above forces a rethinking of such a conclusion. It would appear that it is better to assume that the JewishChristian conflict portrayed in John was a general feature of intraJewish disputes in the first century. Even more, although these disputes certainly intensified as 'Christianity' grew and became more unified, it is likely that the tension had existed from the very beginning of the Christian movement. As Philip Alexander explains:

It is abundantly clear from the New Testament itself that Christianity before 70 not only attracted support but also encountered strong and widespread opposition within the Jewish community. That opposition ranged from central authorities in Jerusalem (the High Priest and the Sanhedrin) to the leaders of the local synagogues. It extended from Palestine (both Galilee and Jerusalem) to the Diaspora (e.g. Asia Minor

44 This corrects Martyn at the literary level as well, for the anachronism he assumed in 9:22 was the key for reading the Gospel as a two-level drama. Therefore, our historical analysis lends support to literary critiques of Martyn, especially that of Tobias Hägerland, 'John's Gospel: A Two-Level Drama?' JSNT 25 (2003): 309-22.

45 C. K. Barrett, The Gospel According to St. John, agrees, 'That the synagogue had already at that time applied a test of Christian heresy is unthinkable' (361). 
and Achaea). It began in the time of Jesus himself and continued unabated in the period after the crucifixion. ${ }^{46}$

More specifically, D. Neale has argued convincingly that during his lifetime Jesus was considered to be a mesith, one who leads people astray, based upon an examination of the Gospel accounts with reference to Deuteronomy $13 .{ }^{47}$ According to Neale,

...the examination of some New Testament texts that reflect a negative response to Jesus in light of literary traditions about the mesith ... shows a reasonable possibility that the hatred reserved for the biblical mesith could have been directed toward Jesus. Furthermore, some enigmatic aspects of the public response to Jesus' ministry are made comprehensible in the light of this interpretation. Deuteronomy 13 and the subsequent mesith tradition provide a valuable addition to our basis for understanding the familial turmoil, civic unrest and personal struggle with loyalty at which the gospels hint. ${ }^{48}$

Such an understanding of Jesus only requires that he was viewed as a problem, a mesith, in his Jewish-familial context. Martyn notices similar language in the Fourth Gospel and claims that the phrase that describes Jesus as the one who is 'leading the people astray' in John 7 'reflects the contemporary drama' in John's own day. ${ }^{49}$ Yet Martyn is willing to admit that Paul himself had been called a deceiver (2 Cor. 6:8; 1 Thess. 2:3). ${ }^{50}$

Maybe even more important to our reading of John 9 is Neale's discussion of the treatment of those connected to the mesith. The rabbinic evidence explains that both the family of the apostate and the town that welcomes him is guilty by association. According to Neale, 'The fierceness of the punishment for the mesith or those who tolerate his activity is remarkable. Judicially both the perpetrator and those who

46 Philip S. Alexander, "The Parting of the Ways" from the Perspective of Rabbinic Judaism,' in James D. G. Dunn (ed.), Jews and Christians: The Parting of the Ways A.D. 70 to 135, WUNT 66 (Tübingen: J. C. B. Mohr, 1992): 19.

47 D. Neale, 'Was Jesus a Mesith? Public Response to Jesus and his Ministry,' TynBul 44 (1993): 89-101.

48 Neale, 'Was Jesus a Mesith?' 101. See also $b$. Sanh. 43a for evidence in Jewish tradition that Jesus was executed for 'deceiving' Israel.

49 Martyn, History and Theology in the Fourth Gospel: 77-79.

50 For a convincing comparison of similar Jewish tensions between John and the early Pauline evidence see David Wenham, 'The Enigma of the Fourth Gospel: Another Look,' TynBul 48 (1997): 149-78. As Wenham explains, 'there is strong evidence indicating that the relevant features of the Fourth Gospel at least have their roots very early in the history of Christianity and long before Jamnia' (152-53). Cf. John A. T. Robinson, The Priority of John (London: SCM Press, 1985): 81-86. 
tolerate the crime are the subject of extreme punishment.' ${ }^{51}$ This would explain much about the Pharisees' approaching of the blind man's parents, their fearful reaction, and their attempt to defer to their grown son. Rather than being an anachronistic intrusion into the narrative, John 9 is looking more and more like familial turmoil common to the first century.

We do not need to look far for similar evidence of familial tensions involving Jesus, for similar evidence is found in the Synoptics. As Beasley-Murray explains:

On the one hand, we must remember that the followers of Jesus suffered much in the manner of the blind man from the time of Jesus on. And ... we must not forget that Jesus himself enunciated the crucial test of discipleship as confession of him before men as Son of Man (Luke 12:8$9=$ Matt 10:32-33; cf. John 9:35); the emphasis in Mark 8:37 on not being ashamed to confess Jesus doubtless expresses the concern in Mark's church of the danger of denial in face of external pressures. Equally significant is the last beatitude in Matt 5:11-12, coming from the later period of Jesus' ministry, the parallel to which in Luke 6:22-23 is remarkably close to John 9: 'Blessed are you when they hate you, and when they exclude you and insult you and cast out your name as evil, because of the Son of Man'. Paul knew what it was to be thrown out of synagogues on mission (Acts 13:50), and he was not alone in that experience. ${ }^{52}$

Even C. H. Dodd, when remarking on 9:22 can state, 'We must ... conclude, it seems, that the prospect of such exclusion was before Christians of Jewish origin early enough, at least, to have entered into the common tradition behind both Luke and John.' ${ }^{53}$ What makes such evidence compelling is that when setting out his methodology in History and Theology in the Fourth Gospel, Martyn declares that 'by comparing John with the Synoptic Gospels we can identify many pieces which are obviously traditional. ${ }^{54}$ Thus, using Martyn's own method, it would seem that 9:22 might actually meet his criterion of 'traditional melodies'. 55

51 Neale, 'Was Jesus a Mesith?' 91.

52 George R. Beasley-Murray, John, 2d ed. WBC 36 (Nashville: Thomas Nelson, 1999): 154.

53 C. H. Dodd, Historical Tradition in the Fourth Gospel (Cambridge: Cambridge University, 1963): 410 (emphasis added).

54 Martyn, History and Theology in the Fourth Gospel: 31.

55 Martyn, History and Theology in the Fourth Gospel: 31. Like Martyn, one need not assume that John's perspective or circumstances did not circumvent the 'telling' of this 
For the Johannine narrative, then, the use of 'already' is important: rather than trying to explain the reader's current situation back to them, the narrative is purposefully attempting to show the necessary similarities between the experiences of Jesus and those who decide to follow him. For the sake of time we shall look at a key text that reflects John's use of 'already'. John 15:18-16:4a is widely recognized to be traditional material. ${ }^{56}$ The passage makes explicit the link between Jesus and those who follow him:

If the world hates you, be aware that it hated me before it hated you. ... If they persecuted me, they will persecute you.... Whoever hates me hates my Father also. ... I have said these things to you to keep you from stumbling. They will put you out of the synagogues. Indeed, an hour is coming when those who kill you will think that by doing so they are offering worship to God. And they will do this because they have not known the Father or me. But I have said these things to you so that when their hour comes you may remember that I told you about them.

This passage is intimately connected to our argument in three ways. First, there is an immediate and necessary link between what happened to Jesus and what will or is happening to the readers. In fact, present tension is always to be seen 'on account of Jesus.' The servant-master motif shows the intimate tie between Jesus and his followers. Second, the Johannine Jesus strengthens the identity formation of the readers by pointing out the incorrect view of God: 'they do not know the one who sent me.' Such language portrays intra-Jewish dialogue and a development of self-identity. The readers are even exhorted to maintain this understanding lest they 'stumble'. The intra-Jewish tension requires buffering on both ends, both outward (out-group) and inward (in-group). Third, the use of ámoouvó $\gamma \omega \gamma$ os in 16:2, is working with the tensions in Jesus' own day, not in contrast to them. The future sense here is no different than the current sense in 9:22 and 12:42-in fact, it is no different from what Jesus experienced. The importance of that link is not to be missed. Even more, when such things occur, they are told to remember that they were forewarned. Such an explicit comment is hardly looking beyond the Johannine Jesus ${ }^{57}$ for information concerning intra-group tension.

tradition, but certainly it has to be regarded as tradition-like enough to be of a firm historical nature.

56 Lindars, 'The Persecutions of Christians in John 15:18-16:4a,' 51-54.

57 This argument does not necessarily imply that the history being portrayed is accurate; this is not an exercise in historical Jesus research. The argument could still 
This understanding of the familial turmoil is exactly what Martyn is unable to explain. Although Martyn certainly paints a picture of conflict in John 9 that is possible, once one leaves that chapter, he or she is unable to make sense of the rest of the narrative without splicing it into two, distinct levels, into a narrative order that is out of sequence with the Johannine narrative's own plot development. Even more, because of the influence given to chapter 9, the rest of the chapters must in some way reflect the life of the second level, or the Johannine community. So, the Nicodemus narrative in John 3 represents some pseudo-Christians who come to faith at some point in the history of the community; and the narrative of the Samaritan woman in John 4 represents some influx of Samaritans late in the community's history. But if our reading is correct, this move by Martyn misses the rhetoric of these passages precisely because of an exaggerated understanding of 'expulsion'. Rather, this paper is arguing that these passages reflect familial turmoil as various 'groups' of the Jewish family are confronted by Jesus, this mesith or $\mathrm{min}$ in their midst, allowing the reader to experience the point of tension through the narrative. Nicodemus is rebuked for being a teacher and needing such basic learning; whereas the Samaritan woman is told that neither her worship nor the Pharisaic Jewish worship is enough; it is not about location, it is about a person-the Christ. Tensions in John 8 that deal specifically with fatherhood also participate in this understanding of the familial tension that Jesus brought - a tension that is forced upon the reader, who is asked at the end of the Gospel to realize that the entire work was written that they might believe that Jesus is the Messiah, not a mesith or a min. The rest of the Gospel has shown that the tensions that this causes - tensions the readers, or at least those who have already believed, are most certainly facing in their own contexts $(9: 22 ; 12: 42)$,

stand even if the picture of Jesus were entirely invented. No matter what the level of historical accuracy, John assumes the past of Jesus for his readers. There are, then, not only good historical reasons to reject the link between John and the Birkat ha-Minim, but also pressing reasons in the Johannine narrative itself. Although the author's own view of the historicity of John is tangential to the argument and is purposely removed from the argument so as to avoid interference, the seriousness with which the Fourth Evangelist treats his own version of the Jesus of history should have some credence in further discussions. See, for example, Eugene M. Lemcio, The Past of Jesus in the Gospels (SNTSMS 68; Cambridge: Cambridge University, 1991), who argues convincingly that all four Gospels make a distinction between past and present. For a related argument in John see D. A. Carson, 'Understanding Misunderstanding in the Fourth Gospel,' TynBul 33 (1982): 59-91. 
or will be facing in the future (16:2) — are specifically linked to Jesus himself.

It seems necessary, therefore, to rethink the historical reconstruction

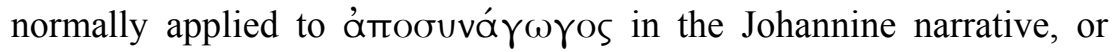
projected onto the circumstances surrounding John. This rethinking in no way tries to remove Jewish-Christian tension and conflict from the realm of the Gospel, it only wants to locate it in a trajectory that is 'already' rooted in the Johannine Jesus, one of many qualified minim in the late first century. It is also necessary, it seems, to give the narrative its voice back, for its explicit development of Jesus is intimately tied, not just loosely affiliated, to the current experiences of the readers. Although John is certainly formed by his situation, he also seems to be arguing for a future formation linked to Jesus himself - even shared experiences between Jesus and the Johannine readers. Such a clear Jewish-Christian or intra-Jewish tension over identity is as pertinent in the later first century as it was during Jesus' own ministry.

\section{Conclusion: A Theological Interest in History}

John Ashton provides an interesting reason for accepting Martyn's reading of the Fourth Gospel: 'Martyn goes on to build an impressive case, which carries conviction because of ... the satisfactory ways it accounts for one of [John's] most puzzling features: why is the Gospel at once so Jewish and yet so anti-Jewish?'58 But this is exactly what our reading has tried to correct. It is specifically the intra-Jewish, familial turmoil that allows John to portray itself as both Jewish and anti-Jewish simultaneously. Historically, the Fourth Gospel portrays familial turmoil rooted in a long history of inter-Jewish tension involving heresy and group identity. John reflects its own identityforming portrayal of the conflict between what later became Judaism and the early Christian movement. As a Gospel, John attempts to link the turmoil experienced by the readers with the experiences of Jesus himself. This does not take away from the fact that real 'expulsions' of whatever kind were taking place behind the Johannine narrative, as witnessed elsewhere in the early Christian movement, ${ }^{59}$ for this was

58 Ashton, Understanding the Fourth Gospel: 109.

59 This understanding of John might help explain other examples of intra-Jewish tension reflected in other New Testament documents. One cannot read Hebrews, the 
part and parcel of what Jesus himself experienced-and what those who had threatened Judaism proper had faced for generations. ${ }^{60}$

attacks against the so-called 'Judaizers' in the letters of Paul, or the Synoptic Gospels without seeing conflict resulting from the familial turmoil necessary for the forming of group identification and unity.

60 Thanks are due to the helpful interaction of an earlier form of this article in the John, Jesus, and History Group at the Annual Meeting of the Society of Biblical Literature, Washington D.C., November 20, 2006. 